\title{
FUNCTIONAL DIVERSITY INFLUENCE IN FOREST WOOD STOCK: A STUDY OF THE BRAZILIAN SAVANNA
}

\author{
INFLUÊNCIA DA DIVERSIDADE FUNCIONAL NO ESTOQUE FLORESTAL: \\ UM ESTUDO DO CERRADO
}

\author{
Milton Serpa de MEIRA JUNIOR ${ }^{1}$; José IMAÑA ENCINAS ${ }^{2}$; \\ José Roberto Rodrigues PINTO²; Sílvia da Luz Lima MOTA ${ }^{3}$ \\ 1. Doutorando em Ciências Florestais, Universidade de Brasília, Brasília, DF, Brasil; 2. Professor do Departamento de Engenharia \\ Florestal, Universidade de Brasília, Brasília, DF, Brasil; 3. Professora da Faculdade de Engenharia Florestal, Universidade Federal do \\ Mato Grosso, Cuiabá, MT, Brasil. milton.serpa@gmail.com
}

\begin{abstract}
Research regarding biodiversity and ecosystem services has been demonstrating a positive correlation among the ecosystem processes, such as the carbon sink into plant biomass and the quantity of carbon in natural vegetation. Nonetheless, it is hard to understand the biodiversity measurements, because they involve gene, phenotypic, population, species, community and ecosystem diversity. The functional diversity refers to the species richness and variety, their characteristics and how that affects the functioning of an ecosystem. Primary productivity is a key factor that affects the functioning of a forest ecosystem. Thus, the aim of this paper was to evaluate the influence of functional diversity on the woody volume productivity (as a proxy for primary production) in the Brazilian savanna. We used six functional characteristics, and to verify the relation between forest production and functional diversity facets, we tested many models. Regarding wood volume, the best models were the exponential and logarithmic. None of the linear models showed significant regression parameters as there was no additive relationship among the multifaceted aspects of functional diversity and wood volume. We found a positive correlation between the functional diversity and primary productivity, which can be used to forecast the effects of diversity variation on ecosystem services.
\end{abstract}

KEYWORDS: Cerrado. Functional traits. Ecosystem services. Functional Ecology.

\section{INTRODUCTION}

The Brazilian savanna or Cerrado is a woodland physiognomy with canopy cover of $10 \%$ to $60 \%$ made up of trees reaching up seven meters (EITEN, 1972). The vegetation is formed mostly by savanna-like vegetation and it occupies almost $70 \%$ of the biome area - around 2 million $\mathrm{km}^{2}$ (SANO et al., 2010). Among the savanna formations, we have the cerrado sensu stricto occurring in well-drained area with deep soils and high altitude (OLIVEIRAFILHO; RATTER, 2002). It is composed by a continuous herbaceous layer with discontinuous and occasional trees (OLIVEIRA-FILHO; RATTER, 2002).

Cerrado presents the highest biodiversity among the global savanna (MITTERMEIER et al., 2005) and is considered one of the biomes with the highest diversity of vascular plants in the world (MENDONÇA et al., 2008). However, the extant area of natural vegetation has been changed into areas of intensive arable crop -agriculture and pastures (SILVA et al., 2006). Human action in Cerrado had already deforested almost $1 / 3$ of the original area (FELFILI et al., 2004), leaving 39.5\% of preserved areas (SANO et al., 2010), as showed on the Figure 1.
Research on biodiversity and ecosystem services has been demonstrating a positive correlation among ecosystem processes, such as carbon sink and plant biomass, and the quantity of carbon in natural vegetation (HUSTON, 1997; TILMAN et al., 2001). Nonetheless, it is hard to understand the biodiversity measurements, because they involve gene, phenotypic, population, species, community and ecosystem diversity (MOUCHET et al., 2010). The classical biodiversity measurements (richness of species or biodiversity index, such as Shannon's and Simpson's) rely on (1) all species are the same or species importance is assessed by relative density; (2) all individuals are similar, independent of their dimension; and (3) the species density were correctly assessed (MAGURRAN, 2004). However, species are not equal when it comes to ecosystem function, making these assumptions invalid (MOUCHET et al., 2010). Diversity measurement incorporates information about the phylogenetic species relation (RICOTTA, 2005) or their functional characteristics (PETCHEY; GASTON, 2006) are better than the classical measurement (CIANCIARUSO; SILVA; et al., 2009). 


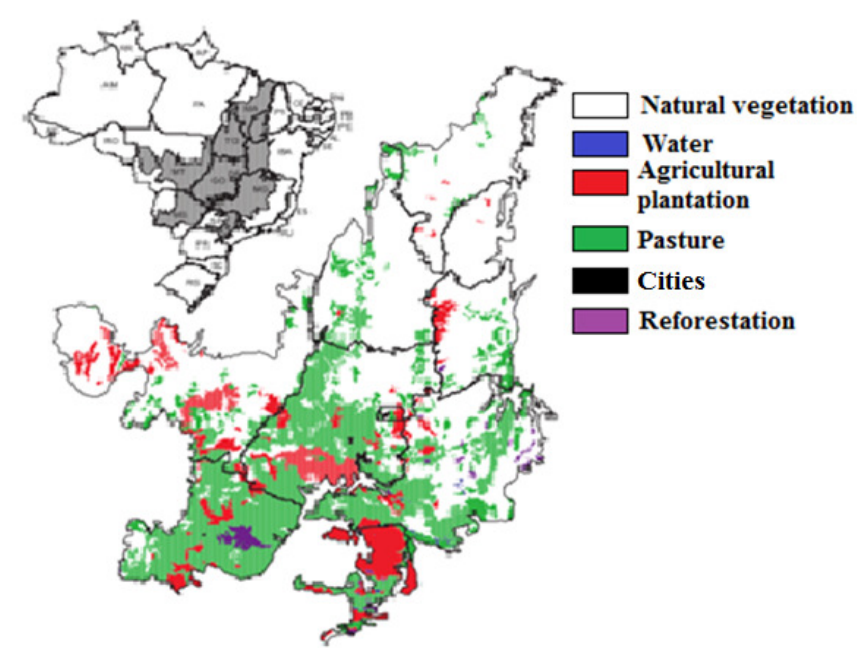

Figure 1. Soil Spatial distribution use classes in Brazilian Savanna, adapted from Sano et al. (2010).

The functional diversity shows species values and range, their characteristics and how that affects the functioning of an ecosystem (TILMAN, 2001). Primary productivity is a key factor that affects the functioning of a forest ecosystem. Many ecologists use the biodiversity gradient, e.g. loss of species at plant communities to test the biodiversity influence in the ecosystem productivity (WANG et al., 2007). Understanding the process of ecosystem services is important to assess the effects of present and future changes on these services in their conservation (CARDINALE et al., 2012).

Functional diversity measures the difference among species based on functional characteristics of an ecosystem (CIANCIARUSO et al., 2009). Functional diversity measures diversity's functional traits that influence ecosystem processes regardless of organisms phylogeny (CIANCIARUSO et al., 2009). Tilman et al. (1997) and Hooper and Vitousek (1997) stated that ecosystems with a great diversity of functional characteristics have a better use of water, nutrients, solar light and high productivity.

Functional communities aspects or wood assemble could be included in the scope of forest management and restoration of degraded areas (KAGEYAMA; GANDARA, 2000). Approach based on functional features is a promising way to elucidate the diversity effects on productivity (ROSCHER et al., 2012), since the functional diversity explains the primary productivity better than the species richness (RUIZ-BENITO et al., 2014). A better understanding of how diversity and dominance affect ecosystems functioning would help to develop strategies of conservation and restoration of threatened or exploited ecosystems (CAVANAUGH et al., 2014). Thus, the aim of this paper was to evaluate the influence of functional diversity regarding volume productivity of woody assembly in a Brazilian Savanna area - cerrado sensu stricto - considering the hypothesis that functional diversity positively affects forest productivity.

\section{MATERIAL AND METHODS}

\section{Characterization and location of the study area}

This study was carried out in a cerrado sensu stricto area located at Fazenda Água Limpa (FAL) at coordinates $15^{\circ} 56^{\prime}-15^{\circ} 59^{\prime} \mathrm{S}$ and $47^{\circ} 55^{\prime}$ $47^{\circ} 58^{\prime} \mathrm{W}$ (has 4,390.0 ha) in Brazilian Federal District (BFD), $20 \mathrm{~km}$ Southern of Brasília, Brazil. The soil on the study area was a yellowish Oxisol, poor in plant nutrients and high in aluminium saturation (BARBOSA et al., 2009).

The average altitude in FAL is $1,100 \mathrm{~m}$ and according to the Köppen classification, the climate is Aw, characterized by two defined seasons, a warmer and rainy season that occurs from October to April, and cold and dry season from May to September, with average temperatures around $22,1^{\circ} \mathrm{C}$ and average annual rainfall around 1,500 mm (ALVARES et al., 2014).

\section{Sampling of vegetation}

The species composition and their abundances were analyzed following the survey conducted by Borges (2009). In this site we implemented ten random plots measuring $20 \times 50 \mathrm{~m}$ $\left(1,000 \mathrm{~m}^{2}\right)$ and all woody stems equal or greater than $5 \mathrm{~cm}$ of diameter at $0.30 \mathrm{~m}$ from ground level were measured in each plot (FELFILI et al., 2005). During the sampling, tree heights and diameters were measured. Plants were identified at species level according to AGP III (CHASE; REVEAL, 2009) using data available in the Missouri Botanic 
Garden (MOBOT), International Plant Names Index (IPNI) and Flora do Brazil.

Primary production on plots was assessed by wood volume $\left(\mathrm{m}^{3}\right)$. The volume of each individual was calculated based on the equation described by (REZENDE et al., 2006) for the woody vegetation in cerrado sensu stricto:

$$
\mathrm{V}=1.09 \times 10^{-4} \times \mathrm{D}^{2} \times 4.51 \times 10^{-4} \times \mathrm{D}^{2} \times \mathrm{H}
$$

diameter $(\mathrm{cm})$
Functional diversity was determined by selecting species with high abundance and that represented $80 \%$ of the whole study community abundance (PAKEMAN; QUESTED, 2007). We used six functional traits: crown dimension, leaf area, wood density and bark density (Table 1 ). We randomized ten individuals for each evaluated species and, from this we evaluated their functional traits.

Table 1. Functional traits used to calculate the functional diversity of woody species in areas of Cerrado sensu stricto, Brasília, Brazil.

\begin{tabular}{|c|c|c|}
\hline Variables & Unit & $\begin{array}{c}\text { Functional Importance } \\
\end{array}$ \\
\hline Life form & Category & Growth potential, resources uptake, biomass area distribution \\
\hline $\begin{array}{l}\text { Crown } \\
\text { dimension }\end{array}$ & $\mathrm{m}^{2}$ & Competition capacity, competitive force, fund-raising, space use \\
\hline $\begin{array}{l}\text { Leaf dry matter } \\
\text { content }\end{array}$ & $\mathrm{mg}$ & $\begin{array}{c}\text { Water and energy equilibrium, associated to algometric factors, nutrients stress } \\
\text { and disturbs on the environment }\end{array}$ \\
\hline $\begin{array}{l}\text { Specific leaf } \\
\text { area }\end{array}$ & $\mathrm{mm}_{1}^{2} \cdot \mathrm{mg}^{-}$ & $\begin{array}{l}\text { Leaf lifespan, leaf structural defences, positively correlated with } \\
\text { potential relative growth rate or mass-based maximum photosynthetic } \\
\text { rate }\end{array}$ \\
\hline Wood density & $\mathrm{mg} \cdot \mathrm{mm}^{-3}$ & Structural strength and carbon stock \\
\hline Bark density & $\mathrm{mg} \cdot \mathrm{mm}^{-3}$ & Structural strength and carbon stock \\
\hline
\end{tabular}

Crown dimension was determined by mean in two perpendicular measurements, where the first measurement was on larger radius of the crown. Regarding the specific basic wood density and bark we used data from a study performed by Vale et al. (2002) at the same place of sampling.

To measure leaf traits of functional diversity (leaf size, leaves' dry mass content and specific leaf area) we took ten adult leaves from each tree without any sign of diseases or attacked by herbivore (PÉREZ-HARGUINDEGUY et al., 2013). Quantification of dry leaf mass was made by the average of dry weight after 24 hours in an oven at $105^{\circ} \mathrm{C}$. Dry weight was divided by leaf mass saturated in water for five hours (PÉREZHARGUINDEGUY et al., 2013). To measure length and leaf area we digitalized five leaves. Using the digital image we calculated the length following the primary vein and the specific leaf area was taken by dividing the leaf area and leaf dry mass mater content (PÉREZ-HARGUINDEGUY et al., 2013). EBImage in the R software Project was used for the task (PAU et al., 2010).

The functional diversity was measured by three multifaceted aspects (divergence, evenness and dispersion) through functional divergence index, functional evenness (VILLÉGER et al., 2008) and functional dispersion (LALIBERTÉ; LEGENDRE, 2010). We calculated each aspect by using the software $\mathrm{R}$ through the package FD (LALIBERTÉ; LEGENDRE, 2010).

Functional divergence measures divergence on the distribution of functional abundance of species in the convex volume (MOUCHET et al., 2010). This divergence was measured through the Fdiv index (Functional Divergence), which quantifies how the specie diverges in the functional space (MOUCHET et al., 2010). The functional evenness is the regularity of the distribution of abundance in niche space, which links all the other species in the traits multidimensional space given by Feve index (Functional Evenness) (VILLEEGER et al., 2008; MOUCHET et al., 2010). The functional dispersion (Fdis) is the average distance of individual species to the centre of mass of all species in the community on a multidimensional space (LALIBERTÉ; LEGENDRE, 2010). Those were calculated using the multivariate dispersion (ANDERSON, 2006).

\section{Data processing}

To verify the relation between forest productivity (volume) and functional diversity (divergence, evenness and dispersion), we tested many models, combining independent variables (functional diversity) and response variable (forest productivity). Thus, we adjusted the regression for each forest productivity variable (excluding death of individuals) and analysed the relation between forest 
Table 2: Model to assess the volume related to functional diversity parameters. V: Wood Volume ( $\left.\mathrm{m}^{3}\right)$, FDiv: Functional divergence; FEve: Functional evenness and FDis: Functional dispersion.

\begin{tabular}{|c|c|}
\hline Model & Equation \\
\hline V1 & $V=\beta_{0}+\beta_{1} F_{E v e}+\beta_{2} F_{D i v}+\beta_{3} F_{D i s}+e$ \\
\hline $\mathrm{V} 2$ & $V=\beta_{0}+\beta_{1} F_{E v e}+\beta_{2} F_{D i v}+\beta_{3} F_{D i v}+\beta_{4}\left(F_{E v e}=F_{D i v}=F_{D i g}\right)+e$ \\
\hline V3 & $L n V=\beta_{0}+\beta_{1} F_{E v E}+\beta_{2} F_{D i s}+\beta_{3} F_{D i v}+\beta_{4}\left(F_{E v z}=F_{D i v} * F_{D i s}\right)+e$ \\
\hline V4 & $L n V=\beta_{0}+\beta_{1} F_{E v s}+\beta_{2} F_{D i s}+\beta_{3}\left(F_{E v \theta}+F_{D i v}+F_{D i s}\right)+e$ \\
\hline V5 & $V=e^{\beta 0}=F_{E v \theta}^{\beta 1} * F_{D i s}^{\beta z}=F_{D i v}^{\beta a}+e$ \\
\hline V6 & $V=e^{\beta 0} * F_{E v e}^{\beta 1} * F_{D i z}^{\beta 2} * F_{D i v}^{\beta z} *\left(F_{E v e} * F_{D i z} * F_{D i v}\right)^{\beta 4}+e$ \\
\hline V7 & $\left.V=\beta_{0}+\llbracket \beta_{1} * \operatorname{Ln}\left(F_{E v Q} * F_{D i g} * F_{D i v}\right)+\beta_{2} \operatorname{Ln}\left(F \rrbracket_{E v Q}\right)+\left[\beta_{3} \operatorname{Ln}(F]_{D i g}\right)+\llbracket \beta_{4} \operatorname{Ln}(E]_{D i v}\right)+e$ \\
\hline V8 & $\left.V=\beta_{0}+\mathbf{【} \beta_{1}+\operatorname{Ln}\left(F_{E v e}\right)+\beta_{2} \operatorname{Ln}(F]_{D E S}\right)+\left[\beta_{3} \operatorname{Ln}(F]_{D i v}\right)+e$ \\
\hline
\end{tabular}

We evaluated the quantity of adjusts by: significance of the parameters, $\mathrm{F}$ value, residual graphic distribution and adjusted coefficient of determination $\left(\mathrm{R}_{\text {Adj }}^{2}\right)$. We adjusted the models by using the $\mathrm{R}$ project software.

\section{RESULTS}

We measured 1,694 trees distributed in 27 families and 56 species (Table 3), and the 42 most abundant species were used to calculate functional diversity. Considering the 56 species identified, 46 was among the hundred most common of cerrado sensu stricto (BRIDGEWATER et al., 2004; RATTER et al., 2006). The species-richest botanic families were Fabaceae (12 species), Vochysiaceace (5 species) e Malpighiaceae (4 species) Fifteen families were represented by a single species. The species with the greatest number of individuals were Roupala montana (127), Ouratea hexasperma (120), Miconia leucocarpa (113), Caryocar brasiliense (110), Eremanthus glomerulatus (109) e Qualea grandiflora (91). Only five species were represented by a single individual.

Table 3. List of woody species with individuals' number (IN) and wood volume (V) in areas of Cerrado sensu stricto, Brasília, Brazil.

\begin{tabular}{lccc}
\hline Species & Family & IN & $\mathbf{V}\left(\mathbf{m}^{\mathbf{3}}\right)$ \\
\hline Roupala montana Aubl. & Proteaceae & 127 & 0.6706 \\
Ouratea hexasperma (A.St.-Hil.) Baill. & Ochnaceae & 120 & 0.8989 \\
Miconia leucocarpa DC. & Melastomataceae & 113 & 0.8657 \\
Caryocar brasiliense Cambess. & Caryocaraceae & 110 & 1.5875 \\
Eremanthus glomerulatus Less. & Asteraceae & 109 & 0.5771 \\
Qualea grandiflora Mart. & Vochysiaceae & 91 & 1.5197 \\
Qualea parviflora Mart. & Vochysiaceae & 79 & 0.8791 \\
Kielmeyera coriacea Mart. \& Zucc. & Calophyllaceae & 78 & 0.3765 \\
Dalbergia miscolobium Benth. & Fabaceae & 77 & 1.0141 \\
Styrax ferrugineus Nees \& Mart. & Styracaceae & 74 & 0.5746 \\
Stryphnodendron adstringens (Mart.) Cov. & Fabaceae & 59 & 0.3693 \\
Piptocarpha rotundifolia (Less.) Baker & Asteraceae & 51 & 0.2246 \\
Erythroxylum suberosum A.St.-Hil. & Erythroxylaceae & 49 & 0.1988 \\
Byrsonima pachyphylla A.Juss. & Malpighiaceae & 40 & 0.1866 \\
Schefflera macrocarpa (Cham. \& Schltdl.) Frodin & Araliaceae & 38 & 0.4311 \\
Palicourea rigida Kunth & Rubiaceae & 37 & 0.1880 \\
Pterodon pubescens (Benth) Benth. & Fabaceae & 23 & 0.1586 \\
Tachigali vulgaris L.F. Gomes da Silva \& H.C. Lima & Fabaceae & 22 & 0.7794
\end{tabular}




\begin{tabular}{|c|c|c|c|}
\hline Species & Family & IN & $\mathbf{V}\left(\mathbf{m}^{3}\right)$ \\
\hline Erythroxylum deciduum A.St.-Hil. & Erythroxylaceae & 20 & 0.0709 \\
\hline Aspidosperma tomentosum Mart. & Apocynaceae & 19 & 0.1097 \\
\hline Qualea multiflora Mart. & Vochysiaceae & 19 & 0.1218 \\
\hline Erythroxylum tortuosum Mart. & Erythroxylaceae & 16 & 0.0689 \\
\hline Myrsine guianensis (Aubl.) Kuntze & Myrsinaceae & 16 & 0.0613 \\
\hline Rourea induta Planch. & Connaraceae & 14 & 0.0556 \\
\hline Byrsonima verbascifolia (L.) DC. & Malpighiaceae & 12 & 0.0679 \\
\hline Connarus suberosus Planch. & Connaraceae & 12 & 0.0460 \\
\hline Eriotheca pubescens (Mart. \& Zucc.) Schott \& Endl. & Malvaceae & 12 & 0.2124 \\
\hline Blepharocalyx salicifolius (Kunth) O.Berg & Myrtaceae & 11 & 0.1807 \\
\hline Byrsonima coccolobifolia Kunth & Malpighiaceae & 11 & 0.0414 \\
\hline Guapira noxia (Netto) Lundell & Nyctaginaceae & 11 & 0.0571 \\
\hline Kielmeyera speciosa A.St.-Hil. & Calophyllaceae & 10 & 0.0401 \\
\hline Machaerium acutifolium Vogel & Fabaceae & 10 & 0.0370 \\
\hline Enterolobium gummiferum (Mart.) J.F.Macbr. & Fabaceae & 8 & 0.0426 \\
\hline Pouteria ramiflora (Mart.) Radlk. & Sapotaceae & 8 & 0.1080 \\
\hline Davilla elliptica A.St.-Hil. & Dilleniaceae & 7 & 0.0322 \\
\hline Heteropterys byrsonimifolia A.Juss. & Malpighiaceae & 7 & 0.0343 \\
\hline Vochysia elliptica (Spr.) Mart. & Vochysiaceae & 7 & 0.0495 \\
\hline Aspidosperma macrocarpon Mart. & Apocynaceae & 6 & 0.0456 \\
\hline Lafoensia pacari A.St.-Hil. & Lythraceae & 5 & 0.0229 \\
\hline Miconia ferruginata DC. & Melastomataceae & 5 & 0.0687 \\
\hline Vatairea macrocarpa (Benth.) Ducke & Fabaceae & 5 & 0.0312 \\
\hline Vochysia thyrsoidea Pohl & Vochysiaceae & 5 & 0.1760 \\
\hline Handroanthus ochraceus (Cham.) Mattos & Bignoniaceae & 4 & 0.0199 \\
\hline Hymenaea stigonocarpa Mart. ex Hayne & Fabaceae & 4 & 0.0468 \\
\hline Plenckia populnea Reissek & Celastraceae & 3 & 0.0242 \\
\hline Salacia crassifolia (Mart. ex Schult.) G.Don & Celastraceae & 3 & 0.0109 \\
\hline Symplocos rhamnifolia A. DC. & Symplocaceae & 3 & 0.0146 \\
\hline Diospyros hispida A.DC. & Ebenaceae & 2 & 0.0091 \\
\hline Leptolobium dasycarpum Vogel & Fabaceae & 2 & 0.0091 \\
\hline Neea theifera Oerst. & Nyctaginaceae & 2 & 0.0086 \\
\hline Tocoyena formosa (Cham. \& Schltdl.) K.Schum. & Rubiaceae & 2 & 0.0081 \\
\hline Dimorphandra mollis Benth. & Fabaceae & 1 & 0.0042 \\
\hline Machaerium opacum Vogel & Fabaceae & 1 & 0.0033 \\
\hline Mimosa claussenii Benth. & Fabaceae & 1 & 0.0038 \\
\hline Psidium salutare (Kunth) O.Berg & Myrtaceae & 1 & 0.0039 \\
\hline Strychnos pseudoquina A.St.-Hil. & Loganiaceae & 1 & 0.0248 \\
\hline
\end{tabular}

The species with high wood volume were $C$. brasiliense, Q. grandiflora, D. miscolobium, and unidentified dead trees. The studied area showed a total wood volume of $14.667 \mathrm{~m}^{3} / \mathrm{ha}$ with a sampling error of $1.099 \mathrm{~m}^{3} \cdot \mathrm{ha}^{-1}$ with a minimum of 1.2374 $\mathrm{m}^{3} \cdot \mathrm{ha}^{-1}$ and maximum value of $1.8754 \mathrm{~m}^{3} \cdot \mathrm{ha}^{-1}$ per plot (Table 4)
Among the tested models, only three of them showed significant regressions (Table 5). Only model V4 presented all parameters significant ( $\mathrm{p}<$ 0.05 ). This model differed from the model V3 by the absence of the FDiv facet. The remaining regressions were not significant. Thus, we evaluated a positive relationship between functional diversity 
and volume (FEve, FDdiv and FDis). But this relationship was logarithmic, ie from a certain functional diversity value onwards, there was a smaller wood volume increase in the community. When it comes to logarithms of the dependent variables (model V7 and V8) or independent, we have obtained significant parameters. The FDiv facet was not a significant parameter in any model. That is, the functional dispersion was not significant for determining the volume.

Table 4. Wood volume $\left(\mathrm{m}^{3}\right)$ per plot in areas of Cerrado sensu stricto, Brasília, Brazil.

\begin{tabular}{cccc}
\hline Plot & Volume $\left(\mathbf{m}^{\mathbf{3}}\right)$ & Plot & Volume $\left(\mathbf{m}^{\mathbf{3}}\right)$ \\
\hline 1 & 1.6530 & 6 & 1.2498 \\
2 & 1.4012 & 7 & 1.5216 \\
3 & 1.3678 & 8 & 1.3031 \\
4 & 1.2374 & 9 & 1.8755 \\
5 & 1.4704 & 10 & 1.5868 \\
\hline
\end{tabular}

Table 5. Models adjusting to quantify wood volume in areas of Cerrado sensu stricto, Brasília, Brazil. $\beta_{\mathrm{i}}$ : Model parameters; p-value: level of significance ANOVA of the regression; S: standard error; $\mathrm{R}^{2}$ adj: adjusted coefficient of determination. *: significant parameter with $95 \%$ probability.

\begin{tabular}{ccccccccc}
\hline Model & $\boldsymbol{\beta}_{\mathbf{0}}$ & $\boldsymbol{\beta}_{\mathbf{1}}$ & $\boldsymbol{\beta}_{\mathbf{2}}$ & $\boldsymbol{\beta}_{\mathbf{3}}$ & $\boldsymbol{\beta}_{\mathbf{4}}$ & $\mathbf{p}$-value & $\mathbf{S}$ & $\mathbf{R}^{\mathbf{2}} \mathbf{a d j}$ \\
\hline V1 & -0.67 & -2.29 & 7.21 & -13.27 & - & 0.288 & 0.183 & 0.16 \\
V2 & 25.99 & -21.04 & -8.22 & -85.78 & 117.46 & 0.127 & 0.145 & 0.47 \\
V3 & $16.85^{*}$ & $-14.07^{*}$ & $-57.89^{*}$ & -5.57 & $79.31^{*}$ & 0.123 & 1.099 & 0.48 \\
V4 & $8.38^{*}$ & $-8.56^{*}$ & $-37.53^{*}$ & $44.12^{*}$ & - & 0.040 & 1.100 & 0.49 \\
V5 & -2.29 & -1.24 & 4.27 & -1.70 & - & 0.002 & & 0.08 \\
V6 & -2.29 & -82.03 & -76.52 & -82.49 & 80.79 & 0.006 & & 0.12 \\
V7 & -2.23 & -1.65 & 5.95 & -2.37 & & 0.250 & 0.143 & 0.19 \\
V8 & 2.62 & -27.68 & 5.61 & $21.52^{*}$ & -0.89 & 0.120 & 0.159 & 0.48 \\
\hline
\end{tabular}

The residual plot for volume (Figure 2) illustrates the models that presented special dependence of residues for the models V1, V5, V6 and V7. Thus, due to the quality of fit, those models were not good to assess the volume. Among the models that present significant regression, the V4 model showed the best results in the relationship observed versus estimated volume (Figure 3). 


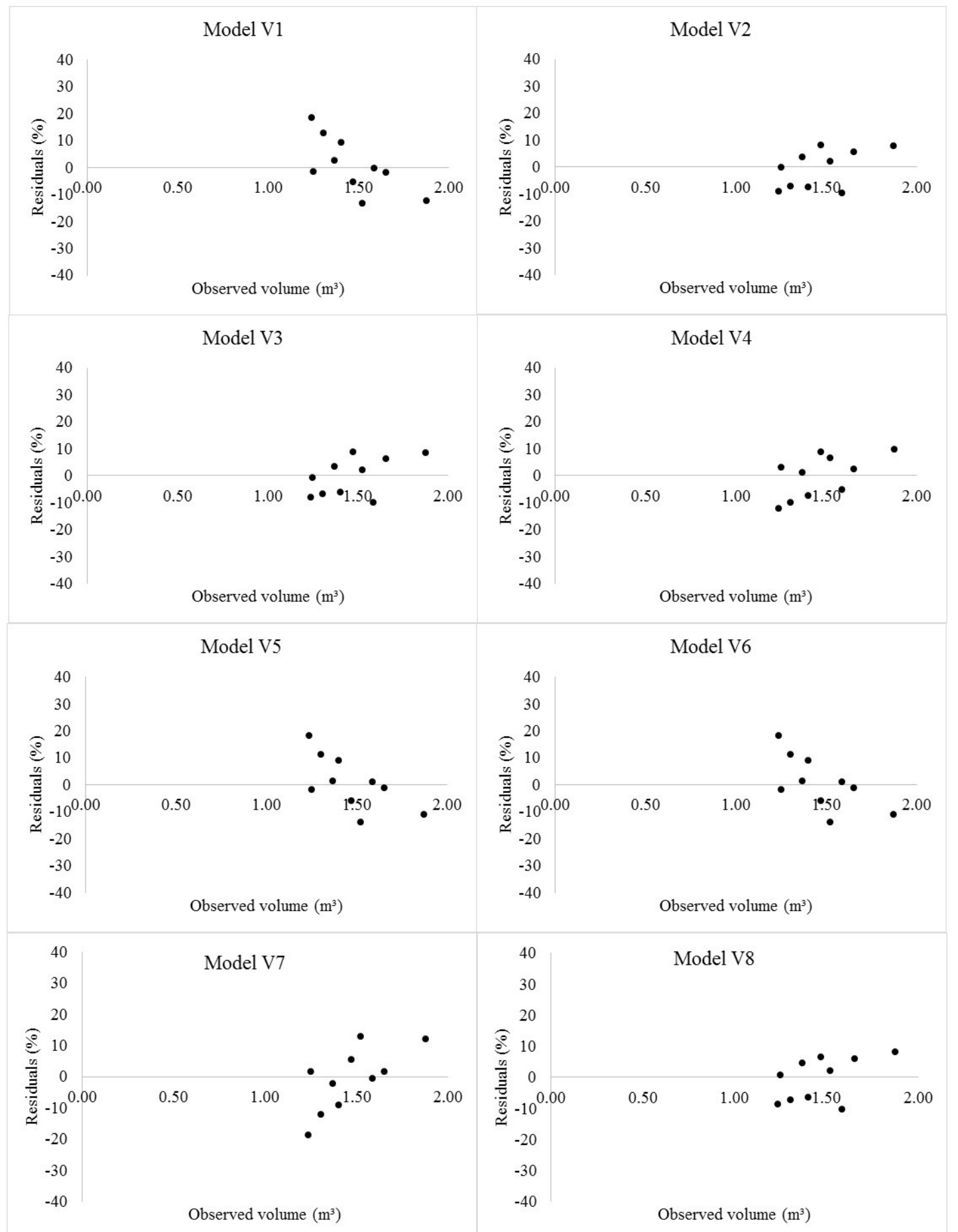

Figure 2. Graphic distribution of residuals on models for wood volume in the study areas of Cerrado sensu stricto, Brasília, Brazil. 

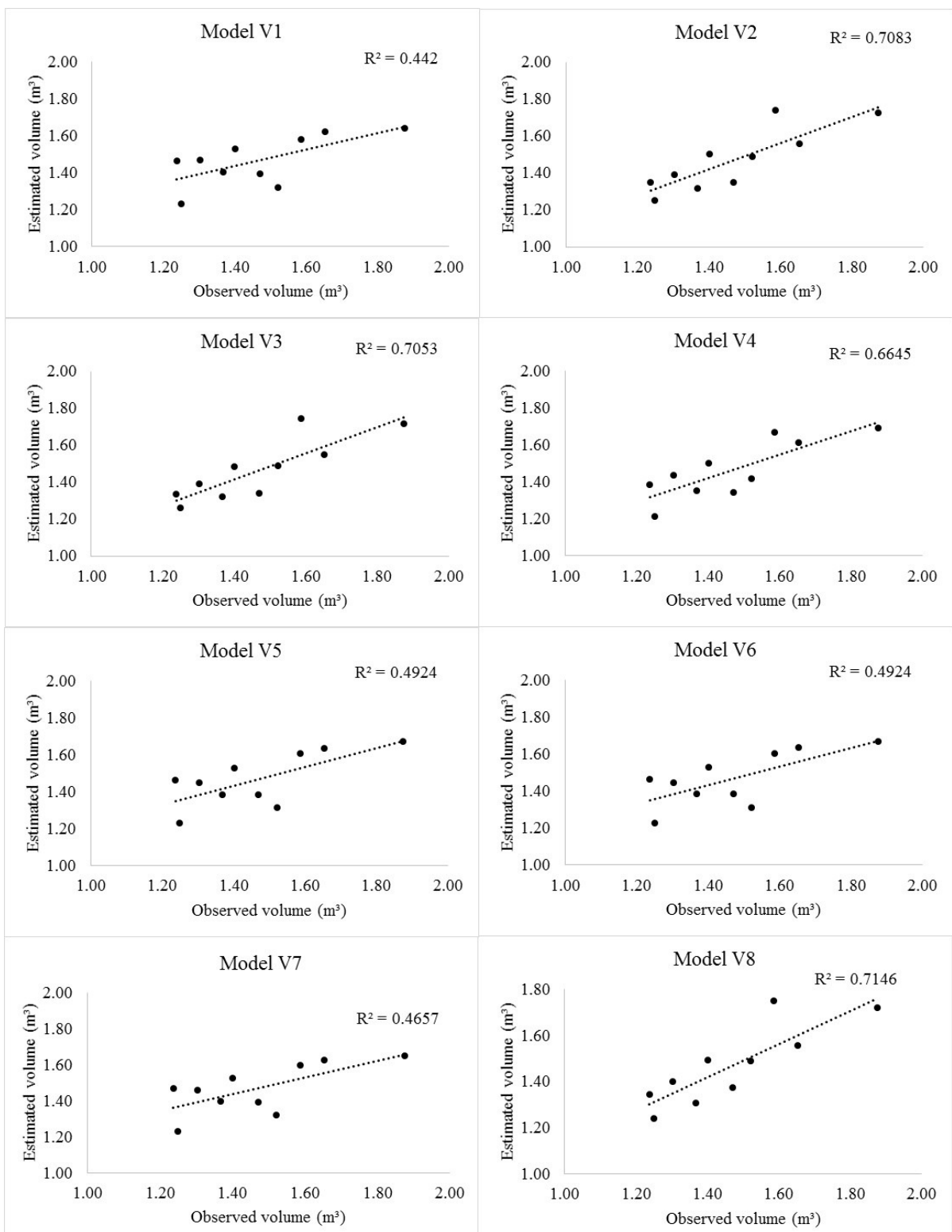

Figure 3. Wood volume observed versus estimated for models tested in areas of Cerrado sensu stricto, Brasília, Brazil.

\section{DISCUSSION}

We found a positive correlation between primary productivity (wood volume) and functional diversity. So, the ecosystem service evaluated in this work, wood volume stock, is affected by functional diversity and their aspects. Also, in a small scale, our data supports the hypothesis that environments with greater functional diversity show higher biomass/wood stock (TILMAN et al., 2001). The positive correlation showed that the volume variation was directly proportional to the functional diversity and its facets. In addition, it increases the evidence that different species groups are important for different processes of ecosystems and biodiversity, especially when ecosystem variety processes are considered (GAMFELDT et al., 2013). Forests with greater functional diversity may present not only greater biomass but also gains in other ecosystem services.

The use of functional diversity as a variable in management planning and recovery of degraded areas could be an important factor to increase the resilience and ecosystem services recovery. To maintain the resilience, a higher functional diversity and functional similarity between dominant species and the less abundant species are important. Thus, in case of perturbation and/or changes in abundance, the least abundant species could replace the dominant and keep the environment resilience (WALKER et al., 1999). 
In our study, plots with greater functional diversity showed higher biomass wood stocks. That stock tends to be higher because of a niche complementation, in other words, species that occupy different niches do not compete against each other for the same resource, being rather complementary (DÍAZ; CABIDO, 2001; CAVANAUGH et al., 2014). Niche complementarily works as a guide for productivity and other ecosystem processes and it is more implicit, especially under conditions with relatively limiting resources when species need to differentiate their resource use strategies to be able to coexist (LOHBECK et al., 2015). When key resources are unlimited, dominant species (those more effectively using resources) can determine the biomass productivity (PAQUETTE; MESSIER, 2011). Other studies show this positive correlation between biomass/wood stock and functional diversity (TILMAN et al., 1996; LOREAU et al., 2001; CARDINALE et al., 2007; ZENG et al., 2012; CONTI; DÍAZ, 2013; ROSCHER et al., 2013; RUIZ-BENITO et al., 2014). Nonetheless, Freitas et al. (2012) have not identified significant relationship between the two variables when they were evaluating the effects of functional diversity on decomposition rate of woody assembly in cerrado sensu stricto. However, it is important to evaluate the effects of functional diversity in small scale, once that they can reveal more details about the mechanism of subjacent biologic stand (WIENS, 1989).

Functional diversity and its facets were able to explain up to $49 \%$ of the volume variation within the assembly. The functional diversity seems to explain the variation in productivity better than the climatic effects (CAVANAUGH et al., 2014; RUIZBENITO et al., 2014), and the effects of soil structure influence the production capacity of volume and biomass (COLE, 1986; RUIZ-BENITO et al., 2014). We can infer that functional diversity can explain the variation of primary productivity better in homogeneous environments in terms of soil and climate.

Primary productivity presents a near asymptote model, which is well adjusted to the logarithmic models. As soil characteristics may limit biomass production, so, it is expected that the present maximum wood volume inventory limit is due to environmental carrying capacity (MCKENDRY, 2002). This explains that the significant adjustments for the studied wood volume and functional diversity facets parameters were those with logarithms models. This corroborates the literature that suggests that logarithmic models are the most appropriate way to associate functional diversity and forest stock (TILMAN et al., 2001).

The models that best explained the variation of primary productivity within the assembly were not linear. Therefore, the facets of the functional diversity are not additive, i.e. complementary. Both aspects are important to clarify the changes on forest stock. In addition to these aspects alone, their interaction was also an important parameter in the explanation of wood volume variation within the assembly. The combination of functional community characteristics and aspects of functional diversity lead to a better evaluation of assembly stock variation than an individual analysis of each functional aspect (ROSCHER et al., 2013).

As we demonstrated in our study, functional diversity was positively related to biomass. Our hypothesis is true, that there is a positive relationship between functional diversity and wood volume on ecosystem services. Therefore, we can use those variables to forecast the effects of functional diversity loss on plant assemblages and communities, and on ecosystem services. With the relationship between functional diversity and ecosystem services better defined, we can quantitatively predict how much functional diversity can influence an ecosystem service. Thus, when applied those theories in the recovery of degraded areas, for example, we can predict what and how much each service will be recovered.

RESUMO: Pesquisas sobre biodiversidade e serviços ecossistêmicos tem demonstrado uma correlação positiva entre os processos do ecossistema, como a absorção de carbono pela biomassa vegetal. No entanto, é difícil entender a medida da biodiversidade, porque ela envolve a diversidade de genes, fenotípica, população, espécie, comunidade e ecossistema. A diversidade funcional ser refere a quantidade e a variedade de espécies, suas características e como isso afeta o funcionamento de um ecossistema. Produtividade primária é um fator chave que afeta o funcionamento de um ecossistema florestal. Assim, o objetivo deste trabalho foi avaliar a influência da diversidade funcional quanto à produtividade de volume de madeira. Usamos seis características funcionais. Para verificar a relação entre a produção florestal e aspectos da diversidade funcional, testamos diversos modelos. Em relação ao volume, os melhores modelos foram os exponenciais e logarítmicos. Nenhum dos modelos lineares mostrou parâmetros significativos ou regressão, ou seja, não existe relação aditiva entre os aspectos multifacetados da diversidade funcional e o volume de madeira. 
Encontramos uma correlação positiva entre a diversidade funcional e a produtividade primária que permite uma melhor previsão dos efeitos das alterações da diversidade funcional sobre os serviços ecossistêmicos.

PALAVRAS-CHAVE: Cerrado. Atributos funcionais. Serviços do ecossistema. Ecologia funcional.

\section{REFERENCES}

ALVARES, C. A.; STAPE, J. L.; SENTELHAS, P. C.; GONÇALVES, J. L. M.; SPAROVEK, G. Köppen's climate classification map for Brazil. Meteorologische Zeitschrift, v. 22, n. 6, p. 711-728, 2014. http://dx.doi.org/10.1127/0941-2948/2013/0507

ANDERSON, M. J. Distance-based tests for homogeneity of multivariate dispersions. Biometrics, v. 62, n. 1, p. 245-53, 2006. Disponível em: <http://www.ncbi.nlm.nih.gov/pubmed/16542252>. Acesso em: 15/7/2014.

BARBOSA, I. O.; LACERDA, M. P. C.; BILICH, M. R. Relações pedomorfogeológicas nas chapadas elevadas do Distrito Federal. Revista Brasileira de Ciência do Solo, v. 33, n. 5, p. 1373-1383, 2009. Disponível em: $<$ http://www.scielo.br/scielo.php?script=sci_arttext\&pid=S0100-

06832009000500029\&lng=pt\&nrm=iso\&tlng=pt $>$. .

BORGES, L. M. Amostragem aleatória de ramos como técnica para quantificar a produção de frutos de Caryocar brasiliense Camb. (Caryocaraceae), 2009. Universidade de Brasília. Disponível em: $<$ www.bibliotecaflorestal.ufv.br/handle/123456789/6258>. .

BRIDGEWATER, S.; RATTER, J. A.; RIBEIRO, J. F. Biogeographic patterns, B-diversity and dominance in the cerrado biome of Brazil. Biodiversity and Conservation, v. 13, n. 12, p. 2295-2317, 2004. Disponível em: <http://link.springer.com/10.1023/B:BIOC.0000047903.37608.4c>. Acesso em: 20/9/2014.

CARDINALE, B. J.; DUFFY, J. E.; GONZALEZ, A.; et al. Biodiversity loss and its impact on humanity. Nature, v. 486, n. 7401, p. 59-67, 2012. Disponível em: <http://www.ncbi.nlm.nih.gov/pubmed/22678280>. Acesso em: 9/7/2014.

CARDINALE, B. J.; WRIGHT, J. P.; CADOTTE, M. W.; et al. Impacts of plant diversity on biomass production increase through time because of species complementarity. Proceedings of the National Academy of Sciences of the United States of America, v. 104, n. 46, p. 18123-8, 2007. Disponível em: $<$ http://www.pubmedcentral.nih.gov/articlerender.fcgi?artid=2084307\&tool=pmcentrez\&rendertype=abstract $>$. Acesso em: 21/10/2014.

CAVANAUGH, K. C.; GOSNELL, J. S.; DAVIS, S. L.; et al. Carbon storage in tropical forests correlates with taxonomic diversity and functional dominance on a global scale. Global Ecology and Biogeography, v. 23, n. 5, p. 563-573, 2014. http://dx.doi.org/10.1111/geb.12143

CHASE, M. W.; REVEAL, J. L. A phylogenetic classification of the land plants to accompany APG III. Botanical Journal of the Linnean Society, v. 161, n. 2, p. 122-127, 2009. Disponível em: $<$ http://onlinelibrary.wiley.com/doi/10.1111/j.1095-8339.2009.01002.x/full>. Acesso em: 30/4/2014.

CIANCIARUSO, M. V.; BATALHA, M. A.; GASTON, K. J.; PETCHEY, O. L. Including intraspecific variability in functional diversity. Ecology, v. 90, n. 1, p. 81-89, 2009. Disponível em: <http://doi.wiley.com/10.1890/07-1864.1>. . http://dx.doi.org/10.1590/S1676-06032009000300008

CIANCIARUSO, M. V.; SILVA, I. A.; BATALHA, M. A. Diversidades filogenética e funcional: novas abordagens para a Ecologia de comunidades. Biota Neotropica, v. 9, n. 3, p. 93-103, 2009.

COLE, M. M. The Savannas: biogeography and geobotany. London: Academic Press, 1986. 
CONTI, G.; DÍAZ, S. Plant functional diversity and carbon storage - an empirical test in semi-arid forest ecosystems. (S. Lavorel, Ed.)Journal of Ecology, v. 101, n. 1, p. 18-28, 2013. Disponível em: <http://doi.wiley.com/10.1111/1365-2745.12012>. Acesso em: 14/11/2013.

DÍAZ, S.; CABIDO, M. Vive la différence: plant functional diversity matters to ecosystem processes. Trends in Ecology \& Evolution, v. 16, n. 11, p. 646-655, 2001. Disponível em: $<$ http://www.sciencedirect.com/science/article/pii/S0169534701022832>. Acesso em: 23/10/2014.

EITEN, G. The Cerrado vegetation of Brazil. The Botanical Review, v. 38, n. 2, p. 201-338, 1972. http://dx.doi.org/10.1007/BF02859158

FELFILI, J. M.; CARVALHO, F. A.; HAIDAR, R. F. Manual para o monitoramento de parcelas permanentes nos biomas Cerrado e Pantanal. 1st ed. Brasilia: Universidade de Brasília, 2005.

FELFILI, J. M.; SILVA JÚNIOR, M. C.; SEVILHA, A. C.; et al. Diversity, floristic and structural patterns of cerrado vegetation in Central Brazil. Plant Ecology, v. 175, n. 1, p. 37-46, 2004. Disponível em: $<$ http://link.springer.com/10.1023/B:VEGE.0000048090.07022.02>. .

FREITAS, J. R.; CIANCIARUSO, M. V.; BATALHA, M. A. Functional diversity, soil features and community functioning: a test in a cerrado site. Brazilian Journal of Biology, v. 72, n. 3, p. 463-70, 2012. Disponível em: <http://www.ncbi.nlm.nih.gov/pubmed/22990816>. .

GAMFELDT, L.; SNÄLL, T.; BAGCHI, R.; et al. Higher levels of multiple ecosystem services are found in forests with more tree species. Nature communications, v. 4, p. 1340, 2013. Disponível em: $<$ http://www.pubmedcentral.nih.gov/articlerender.fcgi?artid=3562447\&tool=pmcentrez\&rendertype=abstract $>$.

HOOPER, D. U.; VITOUSEK, P. M. The Effects of Plant Composition and Diversity on Ecosystem Processes. Science, v. 277, n. 5330, p. 1302-1305, 1997. Disponível em: <http://www.sciencemag.org/cgi/doi/10.1126/science.277.5330.1302>. Acesso em: 18/11/2013.

HUSTON, M. A. Hidden treatments in ecological experiments: re-evaluating the ecosystem function of biodiversity. Oecologia, v. 110, n. 4, p. 449-460, 1997. Disponível em:

$<$ http://link.springer.com/10.1007/s004420050180>. .

KAGEYAMA, P. Y.; GANDARA, F. B. Recuperação de áreas ciliares. In: R. R. Rodrigues; E. F. Leitão Filho (Eds.); Matas ciliares: conservação e recuperação. Editora da ed., p.249-269, 2000. São Paulo.

LALIBERTÉ, E.; LEGENDRE, P. A distance-based framework for measuring functional diversity from multiple traits. Ecology, v. 91, n. 1, p. 299-305, 2010. Disponível em:

<http://www.ncbi.nlm.nih.gov/pubmed/20380219>. .

LOHBECK, M.; POORTER, L.; MARTÍNEZ RAMOS, M.; BONGERS, F. Biomass is the main driver of changes in ecosystem process rates during tropical forest succession. Ecology, v. 96, n. 5, p. 1242-1252, 2015. Disponível em: <http://www.esajournals.org/doi/10.1890/14-0472.1>. .

LOREAU, M.; NAEEM, S.; INCHAUSTI, P.; et al. Biodiversity and ecosystem functioning: current knowledge and future challenges. Science, v. 294, n. 5543, p. 804-8, 2001. Disponível em: $<$ http://www.ncbi.nlm.nih.gov/pubmed/11679658>. Acesso em: 28/2/2013.

MAGURRAN, A. E. Measuring Biological Diversity. Blackwell ed. Oxford, 2004.

MCKENDRY, P. Energy production from biomass (part 1): overview of biomass. Bioresource Technology, v. 83, n. 1, p. 37-46, 2002. Disponível em: <http://linkinghub.elsevier.com/retrieve/pii/S0960852401001183>. . MENDONÇA, R. C.; FELFILI, J. M.; WALTER, B. M. T.; et al. Flora vascular do bioma Cerrado: checklist com 12.356 espécies. In: E. E. Sano; S. P. Almeida; J. F. Ribeiro (Eds.); Cerrado: Ecologia e Flora. Empraba 
Ce ed., p.421-1279, 2008. Planaltina, DF: vol. 2.

MITTERMEIER, R. A.; MITTERMEIER, C. G.; GIL, P. R.; PILGRIM, J. Hotspots Revisited: Earth's

Biologically Richest And Most Endangered Ecoregions. Vancouver, USA: Conservation International, 2005.

MOUCHET, M. A.; VILLÉGER, S.; MASON, N. W. H.; MOUILLOT, D. Functional diversity measures: an overview of their redundancy and their ability to discriminate community assembly rules. Functional Ecology, v. 24, n. 4, p. 867-876, 2010. Disponível em: <http://doi.wiley.com/10.1111/j.1365-2435.2010.01695.x>.

Acesso em: 27/2/2013.

OLIVEIRA-FILHO, A. T.; RATTER, J. A. Vegetation Physiognomies and Woody Flora of the Cerrado Biome. In: P. S. OLIVEIRA; R. J. MARQUIS (Eds.); The Cerrados of Brazil: ecology and natural history of a Neotropical savanna. p.91-120, 2002. New York. http://dx.doi.org/10.7312/oliv12042-005 http://dx.doi.org/10.7312/oliv12042

PAKEMAN, R. J.; QUESTED, H. M. Sampling plant functional traits: What proportion of the species need to be measured? Applied Vegetation Science, v. 10, n. 1, p. 91, 2007. Disponível em:

<http://doi.wiley.com/10.1658/1402-2001(2007)10[91:SPFTWP]2.0.CO;2>. .

PAQUETTE, A.; MESSIER, C. The effect of biodiversity on tree productivity: From temperate to boreal forests. Global Ecology and Biogeography, v. 20, n. 1, p. 170-180, 2011. http://dx.doi.org/10.1111/j.14668238.2010.00592.x

PAU, G.; FUCHS, F.; SKLYAR, O.; BOUTROS, M.; HUBER, W. EBImage-an R package for image processing with applications to cellular phenotypes. Bioinformatics, v. 26, p. 979-981, 2010.

http://dx.doi.org/10.1093/bioinformatics/btq046

PÉREZ-HARGUINDEGUY, N.; DÍAZ, S.; GARNIER, E.; et al. New handbook for standardised measurement of plant functional traits worldwide. Australian Journal of Botany, v. 61, p. 167-234, 2013.

http://dx.doi.org/10.1071/BT12225

PETCHEY, O. L.; GASTON, K. J. Functional diversity: Back to basics and looking forward. Ecology Letters, v. 9, n. 6, p. 741-758, 2006. http://dx.doi.org/10.1111/j.1461-0248.2006.00924.x

RATTER, J. A.; BRIDGEWATER, S.; RIBEIRO, J. F. Biodiversity patterns of the woody vegetation of the Brazilian Cerrado. In: R. T. Pennington; G. P. Lewis; J. A. Ratter (Eds.); Neotropical savannas and seasonally dry forests: plant diversity, biogeography and conservation. Taylor \& F ed., p.31-65, 2006. London.

REZENDE, A. V.; VALE, A. T.; SANQUETTA, C. R.; FIGUEIREDO FILHO, A.; FELFILI, J. M. Comparação de modelos matemáticos para estimativa do volume, biomassa e estoque de carbono da vegetação lenhosa de um cerrado sensu stricto em Brasília, DF. Scientia Forestalis, v. 71, p. 65-76, 2006. Disponível em: $<$ http://www.ipef.br/publicacoes/scientia/nr71/cap07.pdf?origin=publication_detail>. Acesso em: 11/9/2014.

RICOTTA, C. A note on functional diversity measures. Basic and Applied Ecology, v. 6, n. 5, p. 479-486, 2005. Disponível em: <http://linkinghub.elsevier.com/retrieve/pii/S1439179105000435>. Acesso em: $7 / 11 / 2013$.

ROSCHER, C.; SCHUMACHER, J.; GUBSCH, M.; et al. Using plant functional traits to explain diversityproductivity relationships. PloS one, v. 7, n. 5, p. e36760, 2012. Disponível em:

$<$ http://www.pubmedcentral.nih.gov/articlerender.fcgi?artid=3356333\&tool=pmcentrez\&rendertype=abstract>. Acesso em: 8/3/2013.

ROSCHER, C.; SCHUMACHER, J.; LIPOWSKY, A.; et al. A functional trait-based approach to understand community assembly and diversity-productivity relationships over 7 years in experimental grasslands. 
Perspectives in Plant Ecology, Evolution and Systematics, v. 15, n. 3, p. 139-149, 2013. Elsevier GmbH. Disponível em: <http://linkinghub.elsevier.com/retrieve/pii/S1433831913000243>. Acesso em: 18/11/2013.

RUIZ-BENITO, P.; GÓMEZ-APARICIO, L.; PAQUETTE, A.; et al. Diversity increases carbon storage and tree productivity in Spanish forests. Global Ecology and Biogeography, v. 23, n. 3, p. 311-322, 2014. http://dx.doi.org/10.1111/geb.12126

SANO, E. E.; ROSA, R.; BRITO, J. L. S.; FERREIRA, L. G. Land cover mapping of the tropical savanna region in Brazil. Environmental monitoring and assessment, v. 166, n. 1-4, p. 113-24, 2010. Disponível em: <http://www.ncbi.nlm.nih.gov/pubmed/19504057>. Acesso em: 19/11/2013.

SILVA, J. F.; FARIÑAS, M. R.; FELFILI, J. M.; KLINK, C. A. Spatial heterogeneity, land use and conservation in the cerrado region of Brazil. Journal of Biogeography, v. 33, n. 3, p. 536-548, 2006. http://dx.doi.org/10.1111/j.1365-2699.2005.01422.x

TILMAN, D. Functional Diversity. In: S. A. Levin (Ed.); Encyclopedia of Biodiversity. v. 3, p.109-120, 2001. San Diego.

TILMAN, D.; LEHMAN, C. L.; THOMSON, K. T. Plant diversity and ecosystem productivity: Theoretical considerations. Proceedings of the National Academy of Sciences, v. 94, n. 5, p. 1857-1861, 1997. Disponível em: <http://www.pnas.org/cgi/doi/10.1073/pnas.94.5.1857> . http://dx.doi.org/10.1016/B978-0-12384719-5.00061-7

http://dx.doi.org/10.1016/B0-12-226865-2/00132-2

TILMAN, D.; REICH, P. B.; KNOPS, J.; et al. Diversity and productivity in a long-term grassland experiment. Science, v. 294, n. 5543, p. 843-5, 2001. Disponível em: <http://www.ncbi.nlm.nih.gov/pubmed/11679667>. .

TILMAN, D.; WEDIN, D.; KNOPS, J. Productivity and sustainability influenced by biodiversity in grassland ecosystems. Nature, v. 379, p. 718-720, 1996. http://dx.doi.org/10.1038/379718a0

VALE, A. T.; BRASIL, M. A. M.; LEÃO, A. L. Quantificação e caracterização energética da madeira e casca de espécies do cerrado. Ciência Florestal, v. 12, n. 1, p. 71-80, 2002. Disponível em: $<$ http://cascavel.ufsm.br/revistas/ojs-2.2.2/index.php/cienciaflorestal/article/view/1702/977>. .

VILLÉGER, S.; MASON, N. W. H.; MOUILLOT, D. New multidimensional functional diversity indices for a multifaceted framework in functional ecology. Ecology, v. 89, n. 8, p. 2290-301, 2008. Disponível em: $<$ http://www.ncbi.nlm.nih.gov/pubmed/18724739>. .

WALKER, B. H.; KINZIG, A.; LANGRIDGE, J. Plant attribute diversity, resilience, and ecosystem function: The nature and significance of dominant and minor species. Ecosystems, v. 2, n. 2, p. 95-113, 1999. http://dx.doi.org/10.1007/s100219900062

WANG, Z.; YANG, C.; YANG, L.; et al. Relationship and its ecological significance between plant species diversity and ecosystem function of soil conservation in semi-humid evergreen forests, Yunnan Province, China. Frontiers of Forestry in China, v. 2, n. 1, p. 18-27, 2007. Disponível em: $<$ http://link.springer.com/10.1007/s11461-007-0003-6>. Acesso em: 21/10/2014.

WIENS, J. A. Spatial Scaling in Ecology. Functional Ecology, v. 3, n. 4, p. 385, 1989. Disponível em: $<$ http://www.jstor.org/stable/2389612? origin=crossref $>$. Acesso em: 12/10/2014.

ZENG, Y.; JIANG, L.; KE, Y.; et al. The relationship between species diversity and ecosystem function (productivity) of the late Middle Permian brachiopods community at the region of Hechuan, Chongqing, China. Science China Earth Sciences, v. 55, n. 8, p. 1248-1254, 2012. Disponível em: <http://link.springer.com/10.1007/s11430-012-4437-9>. Acesso em: 21/10/2014. 